\title{
Mental Training of College Student Elite Athletes
}

\author{
Murat Turgut $^{1} \&$ Onur Mutlu Yasar ${ }^{1}$ \\ ${ }^{1}$ School of Physical Education and Sport, Kastamonu University, Kastamonu, Turkey \\ Correspondence: Murat Turgut, School of Physical Education and Sport, Kastamonu University, Kastamonu, \\ Turkey. E-mail: mturgut@kastamonu.edu.tr
}

$\begin{aligned} & \text { Received: November 2, } 2019 \\ & \text { Accepted: November 30, 2019 Online Published: December 31, } 2019 \\ & \text { doi:10.5539/jel.v9n1p51 }\end{aligned}$ URL: https://doi.org/10.5539/jel.v9n1p51

\begin{abstract}
In order to achieve the expected high performance, athletes must be physically, technically, tactically and socially ready as well as being psychologically ready and strong (Erdoğan \& Kocaekși, 2015). In this context, mental training of athletes is also important. Mental training means that athletes adjust and control their own sports behavior by adopting specific ways to promote psychological state. Aim of this research was to determine the level of mental training application of professional athletes and differences according to some variables. The sample consisted of 485 professional athletes (University Students) who are still competing in 4 different sports in Turkey (football, handball, basketball and volleyball). Data collection tool consisting of two parts was used in the research. In the first part of the data collection tool, a questionnaire consisting of the personal information of the participants was used. In the second part, Developed by Benkhe et al. (2017) and adapted to Turkish by Yarayan and İlhan (2018), "Mental Training in Sports Inventory" consisting of 5 sub-dimensions and a total of 20 items was used. Non-parametric tests were used for data analysis. Mann-Whitney U was used to determine the difference between two groups, Kruskall-Wallis analysis method was used to determine the difference between more than two groups. The average of total score of Mental Training Scale of the participants was determined as $\bar{X}=3.97$. In other words, the level of mental training of the participants was found to be high. The sub-dimension with the highest average was found to be the Interpersonal Skills sub-dimension with the average of $\bar{X}=4.32$, and the sub-dimension with the lowest average was the Mental Performance Skills sub-dimension with the average of $\bar{X}=3.70$. In addition, different results were determined according to gender and ritual variables.
\end{abstract}

Keywords: athletes, mental training, students

\section{Introduction}

Humans are considered not only as a physical organism but also as a psychological entity with emotions, thoughts, feelings and spirituality (Altıntaş \& Akalan, 2008). Humans are also beings with a high level of such characteristics, and human psychology has taken its place in behavioral sciences and health as an important science. While research on human psychology in general continues, the field of sports psychology has acquired an important role within the sports sciences itself. The field of sport psychology has emerged around the world since the early 1990s, and many researches have been conducted in this field (Patrick, 1914; Buchner, 1903; Cleveland, 1907; Clark, 1930; Tutko, 1970; Martens, 1987; Vaaley, 1994; Strean, 1998; Marsh, 2007; Culver et al., 2003; Awruk \& Janowski, 2016; Smith \& McGannon, 2018; Blodgett et al., 2015; Schinke et al., 2018; Turner et al., 2019). In the last 30 years, especially in terms of increasing the performance of athletes, sport psychology has become an important focus of interest (Baltzell \& Akthar, 2014). In the field of sport psychology, the importance of mental training practices has dramatically increased and the focus on this subject are increasing day by day (Gross et al., 2018; Ong \& Griva, 2017).

In order to achieve the expected high performance, athletes must be physically, technically, tactically and socially ready as well as being psychologically ready and strong (Erdoğan \& Kocaekşi, 2015). In this context, mental training of athletes is also important. Tiger Woods, Serena Williams and Michael Jordan are top athletes who positively talk about the importance of mental training which plays a role in contributing to the success in sport. Mental training is defined as the best option to implement in the minds of the individual and to picture the difficult or easy situations that may happen during competition or training (Ekmekçi, 2015).

Mental training means that athletes adjust and control their own sports behavior by adopting specific ways to 
promote psychological state (Craft et al., 2003). The phenomenon of mental training becomes particularly important when evaluating matches, games or races in which athletes from high level of physical and technical backgrounds face to each other (Cowden, 2016).

The effect of mental training is expected to increase when this technique is implemented together with high quality and adequate physical training, which has a positive effect on skill acquisition in athletes (Kulak et al., 2011). In this context, athletes, coaches and professional managers need to pay attention to mental training as well as physical training (Aldemir et al., 2014). Another important point at this point is to convince especially the athletes about the benefits of mental training practices and to make them feel the importance of mental training (Farres, 2000). Mental skill training requires a certain amount of patience and confidence in its practice because the results may not occur as quickly as in physical training, and the benefits of mental training are more complex and difficult to measure (Strean \& Roberts, 1992).

Mental training types are generally grouped into two main categories with cognitive and somatic methods. Cognitive methods consist of mental rehearsal, mental imagery and visualization, visual motor behavior rehearsal and cognitive behavior therapies. Somatic methods include biological feedback advanced deepening relaxation training and meditation (Behncke, 2004).

Some of the benefits of mental training that can increase the performance of athletes can be expressed as follows (Stuart, 2010):

- Focus

- Self-confidence

- Goal Setting

- Effective Thinking

- Motivation

Some other benefits of mental training include relaxation of the individual and reduction of stress, anxiety, aggressiveness and pressure (Source). In this context, it is thought that mental training will make an important contribution to athletes especially in professional sports.

As a result of abovementioned positive effects of mental training and previous evaluation, the aim of this research was to determinate level of mental training application of professional athletes and differences according to some variables.

\section{Method}

\subsection{Universe Sample}

The sample consisted of 485 professional athletes (university students in different universities) who are still competing in 4 different sports in Turkey (football, handball, basketball and volleyball). According to Krajcie and Morgan (1970), "0.05" tolerance error and the lowest number of samples to be taken from the highest number of universe is 384 , in this context it is seen that the sample size of the research is sufficient.

Within the scope of the research, simple random sampling method was chosen as the sampling method. The simple random sampling method is the sampling method chosen by the researcher in accordance with the researcher's own judgments and eligibility criteria (Etikan et al., 2017). The aim of this method is to reach more participants. 
Table 1. Personnel information of participants

\begin{tabular}{|c|c|c|c|}
\hline Individual Information & Groups & (f) & $(\%)$ \\
\hline \multirow[t]{2}{*}{ Gender } & Woman & 244 & 50.3 \\
\hline & Man & 241 & 49.7 \\
\hline \multirow[t]{3}{*}{ Age } & 18-21 Age & 290 & 59.8 \\
\hline & $22-25$ Age & 109 & 22.5 \\
\hline & 26 Age and Above & 86 & 17.7 \\
\hline \multirow[t]{3}{*}{ Income (Monthly) } & $500-1000 \mathrm{TL}$ & 178 & 36.7 \\
\hline & $1001-2500 \mathrm{TL}$ & 188 & 38.8 \\
\hline & 2501TL and above & 119 & 24.5 \\
\hline \multirow[t]{4}{*}{ Branch } & Basketball & 123 & 25.4 \\
\hline & Football & 142 & 29.3 \\
\hline & Handball & 94 & 19.4 \\
\hline & Volleyball & 126 & 26.0 \\
\hline \multirow[t]{4}{*}{ License Period } & $1-3$ & 71 & 14.6 \\
\hline & $4-7$ & 129 & 26.6 \\
\hline & $8-11$ & 174 & 35.9 \\
\hline & 12 Years and above & 111 & 22.9 \\
\hline \multirow[t]{2}{*}{ Ritual } & Yes & 264 & 54.4 \\
\hline & No & 221 & 45.6 \\
\hline Total & 485 & & \\
\hline
\end{tabular}

\subsection{Data Collection Tool}

Data collection tool consisting of two parts was used in the research. In the first part of the data collection tool, a questionnaire consisting of the personal information of the participants was used. In the second part, Developed by Benkhe et al. (2017) and adapted to Turkish by Yarayan and İlhan (2018), "Mental Training in Sports Inventory" consisting of 5 sub-dimensions and a total of 20 items was used.

\subsection{Data Collection and Analysis}

Data collection tool was applied to professional athletes face-to-face. Participation of the participants in the data collection process was conducted on a voluntary basis. No fee was paid or given to the participants. In the analysis of the data, firstly, the demographic information of the participants and frequency and percentage analysis were used for the answers to the questions.

Then, the participants' data collection tool, their answers to questions, age, gender, income status, branch, license period and ritual variables were examined for the possible differences. normality of the data was applied to decide whether parametric or non-parametric tests would use and it was determined that the data were not normally distribution. In this context, non-parametric tests were used for data analysis. Mann-Whitney U was used to determine the difference between two groups, Kruskall-Wallis analysis method was used to determine the difference between more than two groups.

\section{Results}

According to the analysis of the data obtained from the total score and sub-dimensions of the Mental Training Scale of the participants, it was determined that the data were not normally distributed in both total score and all sub-dimensions according to the Skewness and Kurtosis values (+ 1.96/- 1.96). In this sense, non-parametric tests were used for analysis (Can, 2016).

Table 2. Skewness and Kurtosis values of total score and sub-dimensions in mental training scale

\begin{tabular}{lllll}
\hline Sub Dimensions & $\overline{\mathbf{X}}$ & Ss & Skewness & Kurtosis \\
\hline Mental Basic Skills & 4.09 & .65 & -1.31 & 1.64 \\
Mental Performance Skills & 3.70 & .64 & -.763 & 1.77 \\
Interpersonal Skills & 4.32 & .62 & -1.82 & 1.03 \\
Speaking with Yourself (Inner Speech) & 3.87 & .85 & -1.00 & .930 \\
Mental Animation & 4.01 & .73 & -1.01 & 1.94 \\
Total & $\mathbf{3 . 9 7}$ & $\mathbf{. 5 1}$ & $\mathbf{- 1 . 5 3}$ & $\mathbf{1 . 4 1 3}$ \\
\hline
\end{tabular}


The average of total score of Mental Training Scale of the participants was determined as $\bar{X}=3.97$. In other words, the level of mental training of the participants was found to be high. The sub-dimension with the highest average was found to be the Interpersonal Skills sub-dimension with the average of $\overline{\mathrm{X}}=4.32$, and the sub-dimension with the lowest average was the Mental Performance Skills sub-dimension with the average of $\overline{\mathrm{X}}=3.70$.

Table 3. Mann-Whitney U results of the participants according to gender variable

\begin{tabular}{|c|c|c|c|c|c|c|c|}
\hline Sub Dimensions & Gender & $\mathbf{n}$ & Mean Rank & Sum of Rank & $\mathbf{U}$ & $\mathbf{p}$ & Difference \\
\hline \multirow[t]{2}{*}{ Mental Basic Skills } & Woman (1) & 244 & 238.75 & 58256.0 & 28366.0 & .498 & - \\
\hline & $\operatorname{Man}(2)$ & 241 & 247.30 & 59599.0 & & & \\
\hline \multirow[t]{2}{*}{ Mental Performance Skills } & Woman (1) & 244 & 220.06 & 53695.0 & 23805.0 & .000 & $2>1$ \\
\hline & $\operatorname{Man}(2)$ & 241 & 266.22 & 64160.0 & & & \\
\hline \multirow[t]{2}{*}{ Interpersonal Skills } & Woman (1) & 244 & 245.20 & 59829.0 & 28865.0 & .724 & - \\
\hline & Man (2) & 241 & 240.77 & 58026.0 & & & \\
\hline Speaking with Yourself (Inner & Woman (1) & 244 & 245.09 & 59801.0 & 28893.0 & .738 & - \\
\hline Speech) & Man (2) & 241 & 240.89 & 58054.0 & & & \\
\hline \multirow[t]{2}{*}{ Mental Animation } & Woman (1) & 244 & 245.14 & 59813.0 & 28881.0 & .732 & - \\
\hline & Man (2) & 241 & 240.84 & 58042.0 & & & \\
\hline \multirow[t]{2}{*}{ Total } & Woman (1) & 244 & 234.29 & $\mathbf{5 7 1 6 7 . 5}$ & 27277.5 & .168 & - \\
\hline & Man (2) & 241 & 251.82 & 60687.5 & & & \\
\hline
\end{tabular}

The average scores of the participants according to the gender variable and the average scores from the sub-dimensions are given in Table 3. According to the results of Mann-Whitney $U$ test conducted to determine whether there is a significant difference between male and female participants' mental training levels, statistically significant difference was found only in favor of male participants in the Mental Performance Skills sub-dimension $(\mathrm{U}=238, \mathrm{p}>0.05)$.

Table 4. Kruskal-Wallis results of the participant according to age variable

\begin{tabular}{|c|c|c|c|c|c|c|c|}
\hline Sub Dimensions & Age & $\mathbf{N}$ & Mean Rank & $\overline{\mathbf{X}}$ & $\mathbf{x}^{2}$ & $\mathbf{p}^{*}$ & Difference \\
\hline \multirow[t]{3}{*}{ Mental Basic Skills } & 18-21 Age & 290 & 242.92 & 4.08 & 1.597 & .450 & - \\
\hline & $22-25$ Age & 109 & 231.95 & 4.04 & & & \\
\hline & 26 Age and Above & 86 & 257.26 & 4.19 & & & \\
\hline \multirow[t]{3}{*}{ Mental Performance Skills } & 18-21 Age & 290 & 237.17 & 3.66 & 3.915 & .141 & - \\
\hline & $22-25$ Age & 109 & 237.20 & 3.69 & & & \\
\hline & 26 Age and Above & 86 & 269.99 & 3.86 & & & \\
\hline \multirow[t]{3}{*}{ Interpersonal Skills } & 18-21 Age & 290 & 234.22 & 4.27 & 2.918 & .233 & - \\
\hline & $22-25$ Age & 109 & 256.97 & 4.38 & & & \\
\hline & 26 Age and Above & 86 & 254.90 & 4.38 & & & \\
\hline Speaking with Yourself (Inner & 18-21 Age & 290 & 244.00 & 3.87 & .050 & .975 & - \\
\hline \multirow[t]{2}{*}{ Speech) } & 22-25 Age & 109 & 242.50 & 3.85 & & & \\
\hline & 26 Age and Above & 86 & 240.27 & 3.91 & & & \\
\hline \multirow[t]{3}{*}{ Mental Animation } & 18-21 Age & 290 & 249.63 & 4.05 & 4.511 & .105 & - \\
\hline & $22-25$ Age & 109 & 248.01 & 4.01 & & & \\
\hline & 26 Age and Above & 86 & 214.28 & 3.90 & & & \\
\hline \multirow[t]{3}{*}{ Total } & 18-21 Age & 290 & 239.38 & 3.96 & .808 & .668 & - \\
\hline & 22-25 Age & 109 & 243.28 & 3.97 & & & \\
\hline & 26 Age and Above & 86 & 254.84 & 4.04 & & & \\
\hline
\end{tabular}

The average total scores of the participants according to the age variable and the average scores from the sub-dimensions are given in Table 4. According to the findings, no statistically significant difference was found between the groups in both sub-dimensions and total mean scores. However, it can be stated that perceptions of mental training skills increased with increasing age parameter in comparison of total mean scores of the groups. 
Table 5. Kruskal-Wallis results of the participant according to sport branch variable

\begin{tabular}{|c|c|c|c|c|c|c|c|}
\hline Sub Dimensions & Branch & $\mathbf{N}$ & Mean Rank & $\overline{\mathbf{X}}$ & $\mathrm{x}^{2}$ & p* & Difference \\
\hline \multirow[t]{4}{*}{ Mental Basic Skills } & Basketball & 123 & 229.71 & 4.06 & 4.387 & .223 & - \\
\hline & Football & 142 & 261.50 & 4.17 & & & \\
\hline & Handball & 94 & 230.77 & 4.03 & & & \\
\hline & Volleyball & 126 & 244.25 & 4.07 & & & \\
\hline Mental Performance & Basketball & 123 & 256.12 & 3.77 & 3.191 & .363 & - \\
\hline \multirow[t]{3}{*}{ Skills } & Football & 142 & 240.31 & 3.67 & & & \\
\hline & Handball & 94 & 223.22 & 3.63 & & & \\
\hline & Volleyball & 126 & 247.98 & 3.72 & & & \\
\hline \multirow[t]{4}{*}{ Interpersonal Skills } & Basketball & 123 & 245.61 & 4.32 & 1.793 & .616 & - \\
\hline & Football & 142 & 250.60 & 4.36 & & & \\
\hline & Handball & 94 & 226.65 & 4.26 & & & \\
\hline & Volleyball & 126 & 244.09 & 4.30 & & & \\
\hline \multirow{4}{*}{$\begin{array}{l}\text { Speaking with Yourself } \\
\text { (Inner Speech) }\end{array}$} & Basketball & 123 & 239.48 & 3.84 & 1.176 & .759 & - \\
\hline & Football & 142 & 241.17 & 3.89 & & & \\
\hline & Handball & 94 & 235.62 & 3.81 & & & \\
\hline & Volleyball & 126 & 254.01 & 3.92 & & & \\
\hline \multirow[t]{4}{*}{ Mental Animation } & Basketball & 123 & 230.26 & 3.98 & 3.676 & .299 & - \\
\hline & Football & 142 & 246.61 & 4.01 & & & \\
\hline & Handball & 94 & 231.49 & 3.97 & & & \\
\hline & Volleyball & 126 & 259.95 & 4.07 & & & \\
\hline \multirow[t]{4}{*}{ Total } & Basketball & 123 & 240.76 & 3.98 & 3.292 & .349 & - \\
\hline & Football & 142 & 246.25 & 3.99 & & & \\
\hline & Handball & 94 & 222.68 & 3.91 & & & \\
\hline & Volleyball & 126 & 256.69 & 3.99 & & & \\
\hline
\end{tabular}

The average total scores of the participants according to the branch variable and the average scores from the sub-dimensions are given in Table 5. According to the findings, no statistically significant difference was found between the groups in both sub-dimensions and total mean scores. However, in the total score average of mental training inventory, the branches from the highest to the lowest are respectively Volleyball, Football, Basketball and Handball branches.

Table 6. Mann-Whitney U results of the participants according to ritual variable

\begin{tabular}{|c|c|c|c|c|c|c|c|}
\hline Sub Dimensions & Ritual & $n$ & Mean Rank & Sum of Rank & $\mathbf{U}$ & $\mathbf{p}$ & Difference \\
\hline \multirow{2}{*}{ Mental Basic Skills } & Yes (1) & 264 & 257.92 & 68092.0 & 25232.0 & .010 & $1>2$ \\
\hline & No (2) & 221 & 225.17 & 49763.0 & & & \\
\hline \multirow[t]{2}{*}{ Mental Performance Skills } & Yes (1) & 264 & 247.08 & 65229.0 & 28095.0 & .481 & - \\
\hline & No (2) & 221 & 238.13 & 52626.0 & & & \\
\hline \multirow[t]{2}{*}{ Interpersonal Skills } & Yes (1) & 264 & 250.12 & 66031.0 & 27293.0 & .216 & - \\
\hline & No (2) & 221 & 234.50 & 51824.0 & & & \\
\hline \multirow{2}{*}{$\begin{array}{l}\text { Speaking with Yourself (Inner } \\
\text { speech) }\end{array}$} & Yes (1) & 264 & 260.35 & 68732.0 & 24592.0 & .002 & $1>2$ \\
\hline & No (2) & 221 & 222.28 & 49123.0 & & & \\
\hline \multirow[t]{2}{*}{ Mental Animation } & Yes (1) & 264 & 255.34 & 67411.0 & 25913.0 & .032 & $1>2$ \\
\hline & No (2) & 221 & 228.25 & 50444.0 & & & \\
\hline \multirow[t]{2}{*}{ Total } & Yes (1) & 264 & 257.17 & 67893.0 & 25431.0 & .015 & $1>2$ \\
\hline & No (2) & 221 & 226.07 & 49962.0 & & & \\
\hline
\end{tabular}

Table 6 shows the average scores of the participants in the Mental Training Scale and the sub-dimensions. According to the results of the Mann-Whitney $U$ test which was used to determine whether there is a significant difference between the perceptions of mental training levels of participants with and without ritual, it was found that perceptions of their mental training levels of the participants with ritual were found to be statistically higher in Mental Basic Skills, Self-Speaking (Intrinsic Speech), Mental Rejuvenation subscales and total score averages. 
Table 7. Kruskal-Wallis results of the participant according to year of license variable

\begin{tabular}{|c|c|c|c|c|c|c|c|}
\hline & Year of License & $\mathbf{N}$ & Mean Rank & $\overline{\mathbf{X}}$ & $\mathrm{x}^{2}$ & $p^{*}$ & Difference \\
\hline \multirow{4}{*}{ Mental Basic Skills } & $1-3$ & 71 & 243.76 & 4.10 & .698 & .874 & - \\
\hline & $4-7$ & 129 & 250.22 & 4.10 & & & \\
\hline & $8-11$ & 174 & 242.26 & 4.08 & & & \\
\hline & 12 years and above & 111 & 235.29 & 4.10 & & & \\
\hline Mental Performance & $1-3$ & 71 & 219.63 & 3.62 & 5.831 & .120 & - \\
\hline \multirow[t]{3}{*}{ Skills } & $4-7$ & 129 & 230.62 & 3.64 & & & \\
\hline & $8-11$ & 174 & 248.13 & 3.70 & & & \\
\hline & 12 years and above & 111 & 264.29 & 3.82 & & & \\
\hline \multirow[t]{4}{*}{ Interpersonal Skills } & $1-3$ & 71 & 230.13 & 4.28 & 1.697 & .638 & - \\
\hline & $4-7$ & 129 & 235.70 & 4.25 & & & \\
\hline & $8-11$ & 174 & 251.49 & 4.36 & & & \\
\hline & 12 years and above & 111 & 246.41 & 4.35 & & & \\
\hline \multirow{4}{*}{$\begin{array}{l}\text { Speaking with Yourself } \\
\text { (Inner Speech) }\end{array}$} & $1-3$ & 71 & 235.35 & 3.84 & 1.499 & .683 & - \\
\hline & $4-7$ & 129 & 248.63 & 3.90 & & & \\
\hline & $8-11$ & 174 & 235.64 & 3.81 & & & \\
\hline & 12 years and above & 111 & 252.89 & 3.96 & & & \\
\hline \multirow[t]{4}{*}{ Mental Animation } & $1-3$ & 71 & 225.35 & 3.94 & 2.742 & .433 & - \\
\hline & $4-7$ & 129 & 256.78 & 4.04 & & & \\
\hline & $8-11$ & 174 & 244.49 & 4.01 & & & \\
\hline & 12 years and above & 111 & 235.94 & 4.03 & & & \\
\hline \multirow[t]{4}{*}{ Total } & $1-3$ & 71 & 223.92 & 3.93 & 2.020 & .568 & - \\
\hline & $4-7$ & 129 & 242.10 & 3.95 & & & \\
\hline & $8-11$ & 174 & 244.48 & 3.97 & & & \\
\hline & 12 years and above & 111 & 253.94 & 4.03 & & & \\
\hline
\end{tabular}

The average total scores of the participants included in the study from the Mental Training Scale and the average scores from the sub-dimensions are given in Table 7. According to the findings, no statistically significant difference was found between the groups in both sub-dimensions and total mean scores. However, it can be stated that perceptions of mental training skills increased with the increase of undergraduate year parameter in the comparison of the total mean scores of the groups.

Table 8. Kruskal-Wallis results of the participant according to income variable

\begin{tabular}{|c|c|c|c|c|c|c|c|}
\hline & Income & $\mathbf{N}$ & Mean Rank & $\overline{\mathbf{X}}$ & $\mathrm{x}^{2}$ & $\mathbf{p}^{*}$ & Difference \\
\hline \multirow[t]{3}{*}{ Mental Basic Skills } & $500-1000 \mathrm{TL}$ & 178 & 247.51 & 4.10 & & & \\
\hline & $1001-2500 \mathrm{TL}$ & 188 & 243.58 & 4.11 & .553 & .758 & - \\
\hline & 2501TL and above & 119 & 235.34 & 4.04 & & & \\
\hline \multirow[t]{3}{*}{ Mental Performance Skills } & $500-1000 \mathrm{TL}$ & 178 & 233.56 & 3.66 & & & \\
\hline & $1001-2500 \mathrm{TL}$ & 188 & 246.69 & 3.72 & 1.368 & .505 & - \\
\hline & $2501 \mathrm{TL}$ and above & 119 & 251.29 & 3.73 & & & \\
\hline \multirow[t]{3}{*}{ Interpersonal Skills } & $500-1000 \mathrm{TL}$ & 178 & 246.92 & 4.35 & & & \\
\hline & $1001-2500 \mathrm{TL}$ & 188 & 249.57 & 4.34 & 2.207 & .332 & - \\
\hline & 2501TL and above & 119 & 226.76 & 4.22 & & & \\
\hline Speaking with Yourself (Inner & $500-1000 \mathrm{TL}$ & 178 & 246.46 & 3.89 & & & \\
\hline \multirow[t]{2}{*}{ Speech) } & $1001-2500 \mathrm{TL}$ & 188 & 244.45 & 3.87 & .481 & .786 & - \\
\hline & 2501TL and above & 119 & 235.53 & 3.84 & & & \\
\hline \multirow[t]{3}{*}{ Mental Animation } & 500-1000 TL & 178 & 257.68 & 4.10 & & & \\
\hline & $1001-2500 \mathrm{TL}$ & 188 & 237.30 & 3.96 & 3.361 & .186 & - \\
\hline & 2501TL and above & 119 & 230.05 & 3.96 & & & \\
\hline \multirow[t]{3}{*}{ Total } & 500-1000 TL & 178 & 244.17 & 3.99 & & & \\
\hline & 1001-2500 TL & 188 & 244.36 & 3.98 & .122 & .941 & - \\
\hline & 2501TL and above & 119 & 239.11 & 3.94 & & & \\
\hline
\end{tabular}

The average total scores of the participants according to the Income Status variable and the average scores from the sub-dimensions are given in Table 8 . According to the findings, no statistically significant difference was found between the participant groups in all sub-dimensions and total score averages. However, it can be stated that perceptions of mental training skills increased with the decrease in income status parameter in comparison 
total mean scores of the groups. In other words, it can be said that there is a negative relationship between participants' income status and their perception of mental training skills.

\section{Discussion}

This study was carried out to determine the level of mental training application of professional athletes and differences according to some variables. According to the findings of the study, the average scores of the participants from the mental training inventory were found to be high. According to the results of the study conducted by Nicholls et al. (2009), the mental resistance of male athletes was found to be higher than those of female athletes. In this sense, it is seen that there is a difference between the results of this research and the results of Nicholls et al. The reason for this difference is the content of the sample groups of the two studies. According to the gender variable, the participants do not have different results in many sub-dimensions. The reason for this may be the fact that all participants were elite athletes.

According to the results of the study conducted by Reddy and Berhanu (2016), where the mental endurance levels of the athletes who are doing sports in university teams are measured, it is determined that the athletes who are in the volleyball group have the highest mental resistance. In this sense, it is seen that there is a similarity between the results of this research and the research conducted by Reddy and Berhanu according to the branch variable. According to the results of the research conducted by Garcia and Santana (2018), it was found that the mental skills and endurance of football players increased with increasing age. In this sense, it is seen that there is a similarity between the results of this research and the results of the research carried out by Garcia and Santana according to the age parameter. Cowden (2017) conducted another study in which the mental skills and endurance of footballers were examined and it was stated that according to the results of the study, mental skills increased with age. In this sense, it can be stated that there is partial similarity between the results of the studies examined by Cowden and the results of these studies. According to the results of the research conducted by Connaughton et al. (2018), mental skills of the athletes increase with the increasing their experience

In other words, it is stated that there is an improvement in the mental skills of the athletes with the increase in the time of being athletes. According to the results of another study conducted by Hanton and Jones (1999), it is stated that the basic and advanced mental skills that help maintaining the mental endurance are used effectively with the increasing number of years of athletic career. In this sense, it is seen that these results are partly similar to those of Connaughton et al. And Hanton and Jones.

\section{References}

Aldemir, Y. G., Biçer, T., \& Kale, E. K. (2014). The Effect of Imagery Interventıons on Problem Solvıng Skıll in Elite Athletes. Journal of Sports and Performance Researches, 5(2), 37-45. https://doi.org/10.17155/spd.05118

Altıntaş, A., \& Akalan, C. (2008). Mental Traınıng and Hıgh Performance. Spormetre Journal of Physical Education and Sports Sciences, 6(1), 39-43. https://doi.org/10.1501/Sporm_0000000131

Awruk, K., \& Janowski, K. (2016). Motivation for physical activity and mental health indicators in male gym attendees. Physical Culture and Sport, Studies and Research, 69(1), 65-73. https://doi.org/10.1515/pcssr-2016-0003

Baltzell, A., \& Akhtar, V. L. (2014). Mindfulness meditation training for sport (MMTS) intervention: Impact of MMTS with division I female athletes. The Journal of Happiness \& Well-Being, 2(2), 160-173. https://doi.org/10.1515/pcssr-2016-0003

Behncke, L. (2004). Mental skills training for sports: A brief review. Online J Sport Psychol, 6(1). ISSN: 1536-0431.

Behnke, M., Tomczak, M., Kaczmarek, L. D., Komar, M., \& Gracz, J. (2017). The Sport Mental Training Questionnaire: Development and Validation. Current Psychology, 38(2), 504-516. https://doi.org/10.1007/s12144-017-9629-1

Blodgett, A. T., Schinke, R. J., McGannon, K. R., \& Fisher, L. A. (2015). Cultural sport psychology research: conceptions, evolutions, and forecasts. International Review of Sport and Exercise Psychology, 8(1), 24-43. https://doi.org/10.1080/1750984X.2014.942345

Buchner, E. F. (1903). A quarter century of psychology in america, 1878-1903. American Journal of Psychology, 14, 666-680. https://doi.org/10.2307/1412326

Clark, J. B. M. (1930). Sport Psychology. The North American Review (1821-1940), 230(1), ISSN: 0029-2397, 2329-1907. 
Cleveland, A. A. (1907). The psychology of chess and of learning to play it. American Journal of Psychology, 18(3), 269-308. https://doi.org/10.2307/1412592

Connaughton, D., Wadey, R., Hanton, S., \& Jones, G. (2008). The development and maintenance of mental toughness: Perceptions of elite performers. Journal of Sports Sciences, 26(1), 83-95. https://doi.org/10.1080/02640410701310958

Cowden, R. G. (2016). Competitive performance correlates of mental toughness in tennis: A preliminary analysis. Perceptual and Motor Skills, 123(1), 341-360. https://doi.org/10.1177/0031512516659902

Cowden, R. G. (2017). Mental Toughness and Success in Sport: A Review and Prospect. The Open Sports Sciences Journal, 10, 1-14. https://doi.org/10.2174/1875399X01710010001

Craft, L. L., Magyar, T. M., Becker, B. J., \& Feltz, D. L. (2003). The relationship between the Competitive State Anxiety Inventory-2 and sport performance: A meta-analysis. Journal of Sport and Exercise Psychology, 25(1), 44-65. https://doi.org/10.1123/jsep.25.1.44

Culver, D. M., Gilbert, W. D., \& Trudel, P. (2003). A decade of qualitative research in sport psychology journals: 1990-1999. The Sport Psychologist, 17(1), 1-15. https://doi.org/10.1123/tsp.17.1.1

Ekmekçi, R. (2015). Mental Training in Sports Nadir Book Store. Istanbul, Turkey. ISBN: 9786059440998

Erdoğan, N., \& Kocaekşi, S. (2015). Psychological Characteristics of the Elite Athletes Have Required: Review . Turkey Clinical Journal of Sports Sciences, 7(2), 57-64. https://doi.org/10.5336/sportsci.2014-42993

Farres, L. G. (2000). A mental training tool: Implementing an effective mental skills training program. $B C$ Coach's Perspective, 4(4), 14-17.

García, F. G., \& Santana, J. (2018). Exploring mental toughness in soccer players of different levels of performance. Revista iberoamericana de psicología del ejercicio y el deporte, 13(2), 297-303. ISSN 1886-8576

Gross, M., Moore, Z. E., Gardner, F. L., Wolanin, A. T., Pess, R., \& Marks, D. R. (2018). An empirical examination comparing the mindfulness-acceptance-commitment approach and psychological skills training for the mental health and sport performance of female student athletes. International Journal of Sport and Exercise Psychology, 16(4), 431-451. https://doi.org/10.1080/1612197X.2016.1250802

Hanton, S., \& Jones, G. (1999). The acquisition and development of cognitive skills and strategies: I. Making the butterflies fly in formation. The Sport Psychologist, 13(1), 1-21. https://doi.org/10.1123/tsp.13.1.1

Krejcie, R. V., \& Morgan, D. W. (1970). Determining sample size for research activities. Educational and Psychological Measurement, 30(3), 607-610. https://doi.org/10.1177/001316447003000308

Kulak, A., Kerkez, F. İ., \& Aktaş, Y. (2011). The effect of mental training program on some motor characteristics of 10-12 year old football players. Journal of Sport Sciences, 22(3), 104-114. Retrieved from https://dergipark.org.tr/tr/pub/sbd/issue/16382/171372

Marsh, H. W. (2007). Application of confirmatory factor analysis and structural equation modeling in sport and exercise psychology. Handbook of Sport Psychology, 3, 774-798. https://doi.org/10.1002/9781118270011.ch35

Martens, R. (1987). Science, knowledge, and sport psychology. The Sport Psychologist, 1(1), $29-55$. https://doi.org/10.1123/tsp.1.1.29

Nicholls, A. R., Polman, R. C., Levy, A. R., \& Backhouse, S. H. (2009). Mental toughness in sport: Achievement level, gender, age, experience, and sport type differences. Personality and Individual Differences, 47(1), 73-75. https://doi.org/10.1016/j.paid.2009.02.006

Ong, N. C., \& Griva, K. (2017). The effect of mental skills training on competitive anxiety in schoolboy rugby players. International Journal of Sport and Exercise Psychology, 15(5), 475-487. https://doi.org/10.1080/1612197X.2016.1153129

Patrick, G. T. W. (1914). The psychology of play. The Pedagogical Seminary, 21(3), 469-484. https://doi.org/10.1080/08919402.1914.10532702

Reddy, V. R., \& Berhanu, B. (2016) Mental toughness in sport: In case of Mekelle university sport teams. International Journal of Applied Research, 2(3), 01-03. ISSN Online: 2394-5869.

Schinke, R. J., Stambulova, N. B., Si, G., \& Moore, Z. (2018). International society of sport psychology position stand: Athletes' mental health, performance, and development. International Journal of Sport and Exercise 
Psychology, 16(6), 622-639. https://doi.org/10.1080/1612197X.2017.1295557

Smith, B., \& McGannon, K. R. (2018). Developing rigor in qualitative research: Problems and opportunities within sport and exercise psychology. International Review of Sport and Exercise Psychology, 11(1), 101121. https://doi.org/10.1080/1750984X.2017.1317357

Strean, W. B. (1998). Possibilities for qualitative research in sport psychology. The Sport Psychologist, 12(3), 333-345. https://doi.org/10.1123/tsp.12.3.333

Strean, W. B., \& Roberts, G. C. (1992). Future directions in applied sport psychology research. The Sport Psychologist, 6, 55-65. https://doi.org/10.1123/tsp.6.1.55

Stuart, M. E. (2009). Mental skills training for sport. Cognella Academic Publishing. Printed in the United States of America ISBN: 978-1-935551-02-7.

Turner, M. J., Carrington, S., \& Miller, A. (2019). Psychological distress across sport participation groups: The mediating effects of secondary irrational beliefs on the relationship between primary irrational beliefs and symptoms of anxiety, anger, and depression. Journal of Clinical Sport Psychology, 13(1), 17-40. https://doi.org/10.1123/jcsp.2017-0014

Tutko, T. A. (1970). Some Clinical Aspects of Sport Psychology. Quest, 13(1), 12-17. https://doi.org/10.1080/00336297.1970.10519671

Vealey, R. S. (1994). Current status and prominent issues in sport psychology interventions. Medicine \& Science in Sports \& Exercise, 26(4), 495-502. ISSN Print: 0195-9131. https://doi.org/10.1249/00005768-199404000-00015

Yarayan, Y. E., \& İlhan, E. L. (2018). The Sport Mental Training Questionnaire (SMTQ) Adaptation Study. Gazi Journal of Physical Education and Sport Sciences, 23(4), 205-218. Retrieved from https://dergipark.org.tr/tr/download/article-file/546418

\section{Copyrights}

Copyright for this article is retained by the author, with first publication rights granted to the journal.

This is an open-access article distributed under the terms and conditions of the Creative Commons Attribution license (http://creativecommons.org/licenses/by/4.0/). 